\title{
Sucrose Phosphorylase and Invertase Activities in Bacteria
}

\author{
K. Balasubramaniam and P. N. Kannangara \\ Department of Biochemistry, Faculty of Medicine, University of Colombo, Colombo, Sri Lanka.
}

(Date of receipt: 31 March 1982)

(Date of acceptance : 13 July 1982)

\begin{abstract}
Leuconostoc species from coconut toddy and from cabbage, Acetobacter xylinum and a Klebsiella species were grown in a sucrose-phosphate medium. The Klebsiella sp. had the fastest rate of growth followed by Leuconostoc from cabbage, Acetobacter xylinum and Leticonostoc from toddy. The time taken by them to reach the late $\log$ phase was $9-10 \mathrm{~h}, 12-14 \mathrm{~h}, 24-30 \mathrm{~h}$ and $60-72 \mathrm{~h}$ respectively. The invertase firom all four species was found in the $20,000 \mathrm{~g}$ supernatant. The activity of invertase in $A$. xylinum, Letuconostoc (toddy), Klebsiella and Letuconostuc (cabbage) was 0.66, 8.06, 45.0 and 77.7 units per $\mathrm{mg}$ protein respectively. Invertase was inactivated when the crude enzyme preparation was stored at $0^{\circ} \mathrm{C}$ in half saturated neutral ammonium sulphate solution for 2 to 3 days. The invertase of Kiensieila and that of Leuconostoc sp from cabbage were inhibited by $5 \times 10^{-2}$ M EDTA to the extent of $85 \%$ and $67 \%$ respectively suggesting that it may be a metallo-enzyme. The growth rate of the Klebsiella sp. was decreased by two-fold when $5 \times 10^{-2}$ M EDTA was present in the culture medium. Sucrose phosphorylase activity was detected ir the $20,000 \mathrm{~g}$ supernatant of A.xyiinum. This enzyme could not be detected in the other three bacteria even after the inhibition of invertase and phosphatase activities.
\end{abstract}

\section{Introduction}

The synthesis of sucrose in plants is catalysed by the enzyme sucrose synthetase. The energy required for this process is obtained by the plants from sunlight. The synthesis of sucrose in the laboratory without the investment of energy has been approached in two ways. The original approach utilized the reversal of the invertase reaction. The recent method called the "phosphate process" uses the reversal of the sucrose phosphorylase reaction. ${ }^{3}$ The energized glucose-1-phosphate required for this process is obtained by the action of starch phosphorylase on starch in which the energy of the glucosidic bond in starch is conserved in glucose-1-phosphate. The overall reactions are shown in Figure 1.

Of the two sucrose hydrolyzing enzymes, invertases are widely distributed among the microorganisms. Much work has been done on yeast and mould invertases ${ }^{9}$ but very little attention has been paid to bacterial invertase.

Unlike invertase, sucrose phosphorylase is not widely distributed among the microoganisms. Upto date it has been found only in Pseudomonas saccharophila, ${ }^{5}$ Pseudomonas putrefaciens ${ }^{6}$ and Leviconostoc mesenteroides. ${ }^{8}$ The preparations of sucrose phosphorylase from $P$. putrefaciens are not stable. Therefore most of the research has been done with sucrose phosphorylase of $P$. saccharophila and $L_{*}$. mesenteroides. 


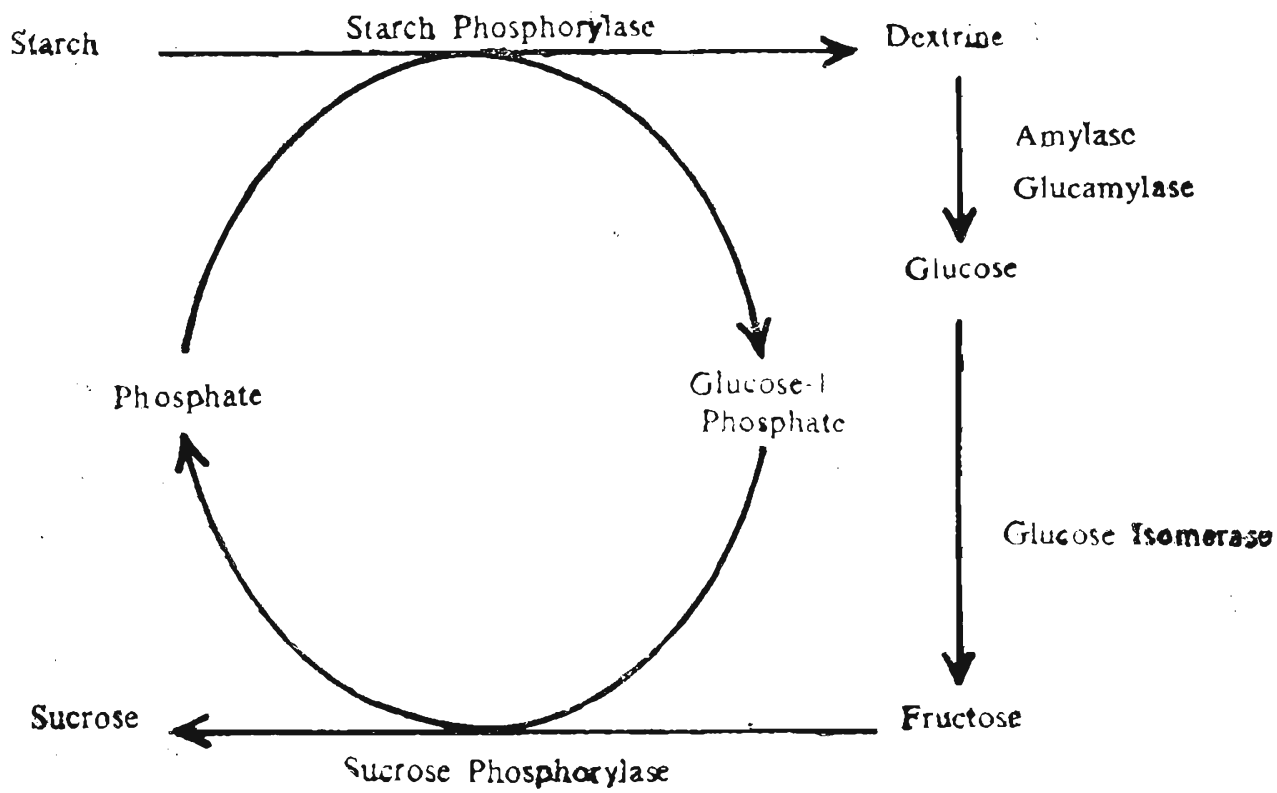

Figure 1. The synthesis of sucrose from starch by the enzyme catalysed phosphate process.

In this investigation a search for sucrose phosphorylase was made by studying the sucrose hydrolyzing enzymes of four locally found sucrose utilizing bacteria. The bacteria used were two species of Leuconostoc, Klebsiella sp. and Acetobacter xylinum.

\section{Experimental}

\subsection{Identification and isolation of bacteria.}

The species of Klebsiella was obtained from the department of Microbiology, Faculty of Medicine, University of Colombo and the Acetobacter xylinum from the Industrial Development Board, Moratuwa. The species of Leuconostoc were isolated from fresh toddy (pH 5.0) and from the outer leaves of cabbage. These two Leliconostoc species were jdentified by their physical appearance. ${ }^{4}$

\subsection{Culture medium}

The culture medium ${ }^{12}$ contained $0.033 \mathrm{M} \mathrm{KH}_{2} \mathrm{PO}_{4}-\mathrm{Na}_{2} \mathrm{HPO}_{4}$ buffer (pH 6.5), $0.1 \%$ $\mathrm{NH}_{4} \mathrm{Cl}, 0.05 \% \mathrm{MgSO}_{4}, 0.005 \%$ Ferric ammonium citrate, $0.001 \% \mathrm{CaCl}_{2}, 0.5 \%$ sucrose and distilled water. This medium was autoclaved at 15 pounds pressure for $10 \mathrm{~min}$. 


\subsection{Growth of bacteria}

All species were grown under aerobic conditions at room temperature $\left(27^{\circ}-30^{\circ} \mathrm{C}\right)$ : Klebsiella needed vigorous aeration. A. xylinum was grown at $\mathrm{pH} 5.5$ while the other three species grew best at $\mathrm{pH} 6.5$. In all cases, the inoculum constituted $10 \%$ $(\mathrm{V} / \mathrm{V})$ of the culture medium and cultures in log phase were used for inoculation.

\subsection{Measurement of bacterial growth}

Bacterial growth was measured by the "Dilution plating technique" or by measuring the turbidity in a Klett-Summerson colorimeter (filter No. 52). ${ }^{12}$

\subsection{Harvesting of bacteria and the preparation of the crude enzyme extract.}

Bacteria were harvested during the late log phase of growth. The crude extract was prepared at $4^{\circ} \mathrm{C}$ according to the flow chart in Figure 2.

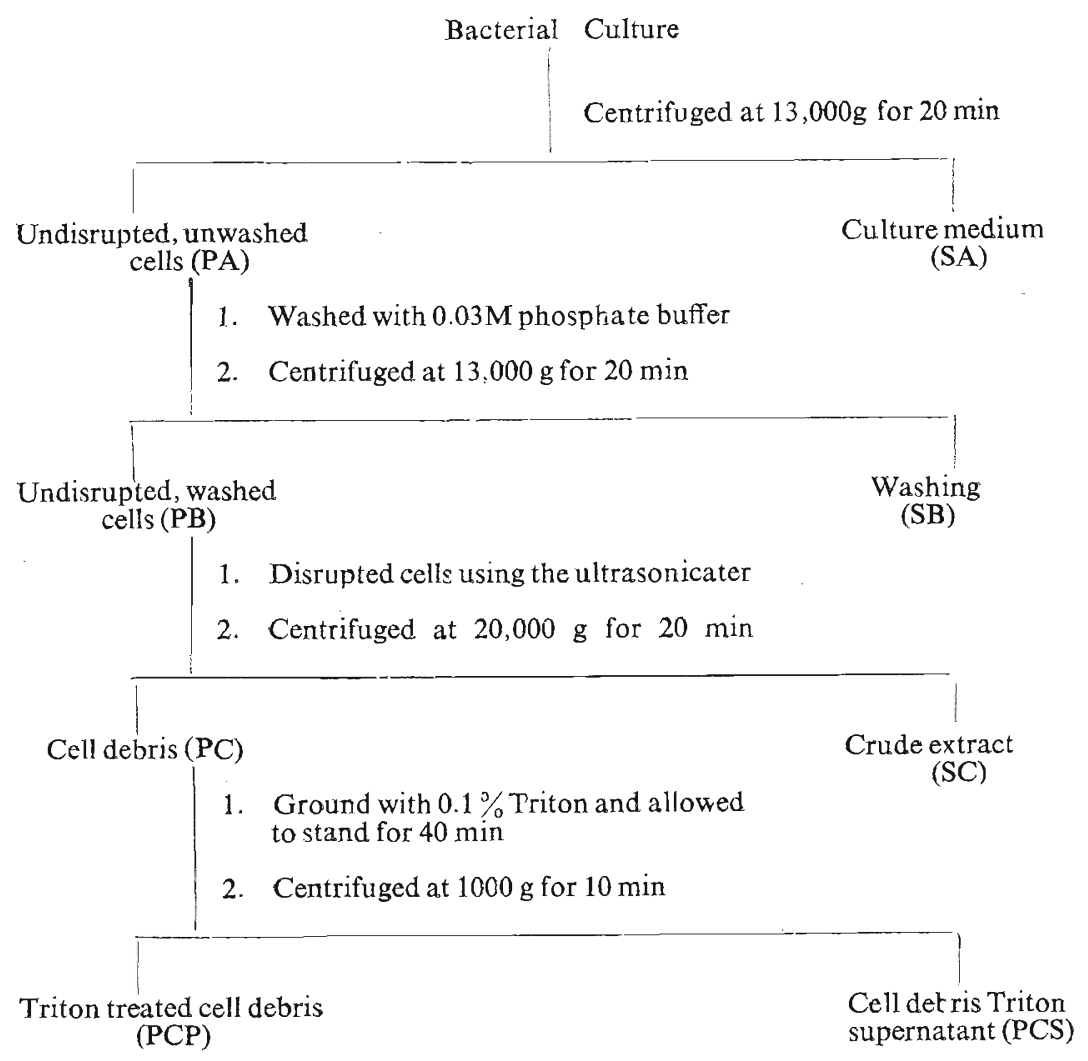

Figure 2. The preparation of crude enzyme extract from bacterial cells 


\subsection{Assay for enzymes.}

\subsubsection{Invertase}

Invertase activity was measured by incubating appropriate amounts of enzyme in $0.033 \mathrm{M}$ phosphate buffer ( $\mathrm{pH} 6.7$ ) confaining $0.2 \mathrm{M}$ sucrose at $37^{\circ} \mathrm{C}$ for $1 \mathrm{~h}$. The total volume of the incubation mixture was $2.0 \mathrm{ml}$. The reducing sugars formed were measured using the DNS (dinitrosalicylic acid) reagent at $540 \mathrm{~nm}^{7}$ A unit of invertase activity is defined as the amount of enzyme which releases $1 \mu$ mole of reducing sugar per hour at $37^{\circ} \mathrm{C}$ under the given experimental conditions.

\subsubsection{Sucrose Phosphorylase}

Sucrose phosphorylase was assayed by measuring the rate of reduction of NADP in a coupled system consisting of sucrose phosphorylase, phosphoglucomutase and glucose-6-phosphate dehydrogenase. ${ }^{12}$ The assay mixture contained potassium phosphate buffer pH $7.0(0.033 \mathrm{M})$, sucrose $(0.08 \mathrm{M}), \mathrm{MgSO}_{4}$ $\left(6 \times 10^{-4} \mathrm{M}\right), \mathrm{NADP}\left(5 \times 10^{-4} \mathrm{M}\right)$, phosphoglucomutase $(90 \mu \mathrm{l}$ containing $50 \mu \mathrm{g})$, glucose -6 -phosphate dehydrogenase $(90 \mu \mathrm{l}$ contajining $5 \mu \mathrm{g})$ and the test solution (enzyme extract). The total volume of the reaction mixture was $3 \mathrm{ml}$. The increase in optical density was measured at $340 \mathrm{~nm}$ using a Pye-Unicam, SP 800 recording Spectrophotometer.

\subsection{Estimation of protein}

Protein was estimated by the method of Lowry et al. ${ }^{10}$

\section{Results and Discussion}

\subsection{Identification of bacteria}

Both the toddy bacterium and the cabbage bacterium formed a film of polysaccharide on the surface of the culture medium after two days of incubation. This biochemical criterion was used to identify them as Leuconostoc. They also had the physical appearances assigned to Leuconostoc. The colonies of toddy and cabbage species were light brown and white in colour respectively, but they were both gummy in nature.

\subsection{Measurement of bacterial growth}

The growth curves for the four bacteria are shown in Figure 3. Klebsiella reached the late $\log$ phase of growth in 9-10h of incubation. The species of Leuconostoc (cabbage) and $A$. xylinum reached the late log phase in $10-12 \mathrm{~h}$ and $24-30 \mathrm{~h}$ respectively. Lecconostoc sp. (toddy) had the slowest growth rate and reached the late log phase in $60-72 \mathrm{~h}$. 


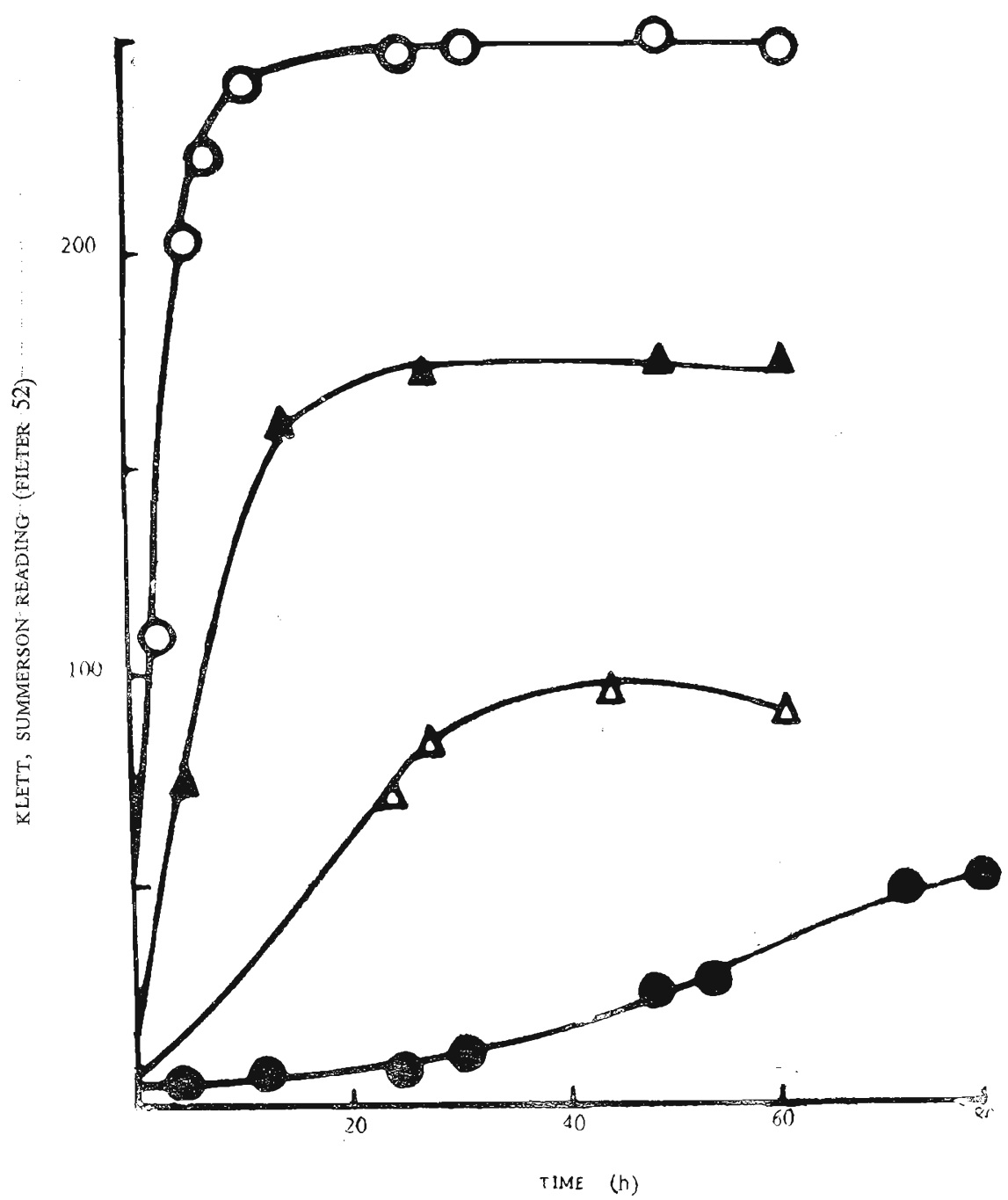

Figure 3. Growth curves of bacteria. $\bigcirc-\bigcirc$, Klebsielia sp.; $\mathbf{A}-\mathbf{\Lambda}$, Leuconostoc sp, (Cabbage): $\Delta-\Delta$, Acetobacter xylinum: $\bullet-$, Leuconostoc sp. (toddy) 


\subsection{Enzyme activity}

The culture medium (SA), crude extract (SC), and the cell debris triton supernatant (PCS) were assayed for invertase and sucrose phosphorylase as described in 2.6.1 and 2.6.2 respectivly. Invertase activity was found in the crude extract of all four bacteria (Table 1 )and not in the culture medium and in the cell debris triton supernatant. This shows that the invertase in all four bacteria is not membrane bound and it is found in the soluble fraction after cell disruption. Furthermore, as in the case of yeast ${ }^{9}$, the invertase in these bacteria is not released into the culture medium.

TABLE 1. Measurement of Invertase Activity

\begin{tabular}{lcccccc}
\hline $\begin{array}{l}\text { Type of } \\
\text { bacteria }\end{array}$ & Sample & $\begin{array}{l}\text { Total } \\
\text { volume } \\
(\mathrm{ml})\end{array}$ & $\begin{array}{l}\text { Protein } \\
(\mathrm{mg} / \mathrm{ml})\end{array}$ & $\begin{array}{l}\text { Enzyme } \\
\text { activity units } \\
(\mu \text { moles/hr) }\end{array}$ & $\begin{array}{l}\text { Specific } \\
\text { activity } \\
\text { (units/mg Protein) }\end{array}$ & $\begin{array}{c}\text { Total activity } \\
\text { (units) }\end{array}$ \\
\hline Klebsiella & SA & 500 & 0 & 0 & 0 & 0 \\
& SC & 25 & 0.16 & 7.2 & 45.0 & 180.0 \\
& PCS & 10 & 0.26 & 0 & 0 & 0 \\
Yeuconostoc & SA & 500 & 0 & 0 & 0 & 0 \\
(Cabbage) & SC & 80 & 0.09 & 7.0 & 77.7 & 560 \\
& PCS & 20 & 0.53 & 0 & 0 & 0 \\
Leuconostoc & SA & 500 & 0 & 0 & 0 & 0 \\
(Toddy) & SC & 20 & 0.61 & 4.92 & 8.06 & 98.4 \\
& PCS & 20 & 0.49 & 0 & 0 & 0 \\
Acetobacter & SA & 500 & 0 & 0 & 0 & 0 \\
xylinum & SC & 25 & 0.30 & 0.20 & 0.66 & 5.0 \\
& PCS & 20 & 0.25 & 0 & 0 & 0 \\
\hline
\end{tabular}

SA, culture medium; SC, crude extract; PCS, cell debris triton supernatant.

The specific activities of invertase in Acetobacter xylinum, in the Leuconostoc from toddy, in the Klebsiella and in the Leuconostoc from cabbage are 0.66, 8.06, 45.0 and 77.7 units / $\mathrm{mg}$ protein respectively. Specific activity of invertase appears not to be related to the growth rate of the bacteria.

Sucrose phosphorylase activity was seen only in the soluble fraction of Acetobacter xylinum. The little increase in absorbance at $340 \mathrm{~nm}$ observed in the control (Figure 4) is probably due to the presenee of small amounts of endogenous substrates.

Phosphorolysis of sucrose by sucrose phosphorylase conserves energy. Although having this enzyme appears to be advantageous for an organism, evolution appears to have selected the non-energy conserving pathway for sucrose utilization using invertase. This is evident from our results in that all the four bacteria havc invertase while only one of them $(A . \quad x y l i n u m)$ has sucrose phosphorylase. 


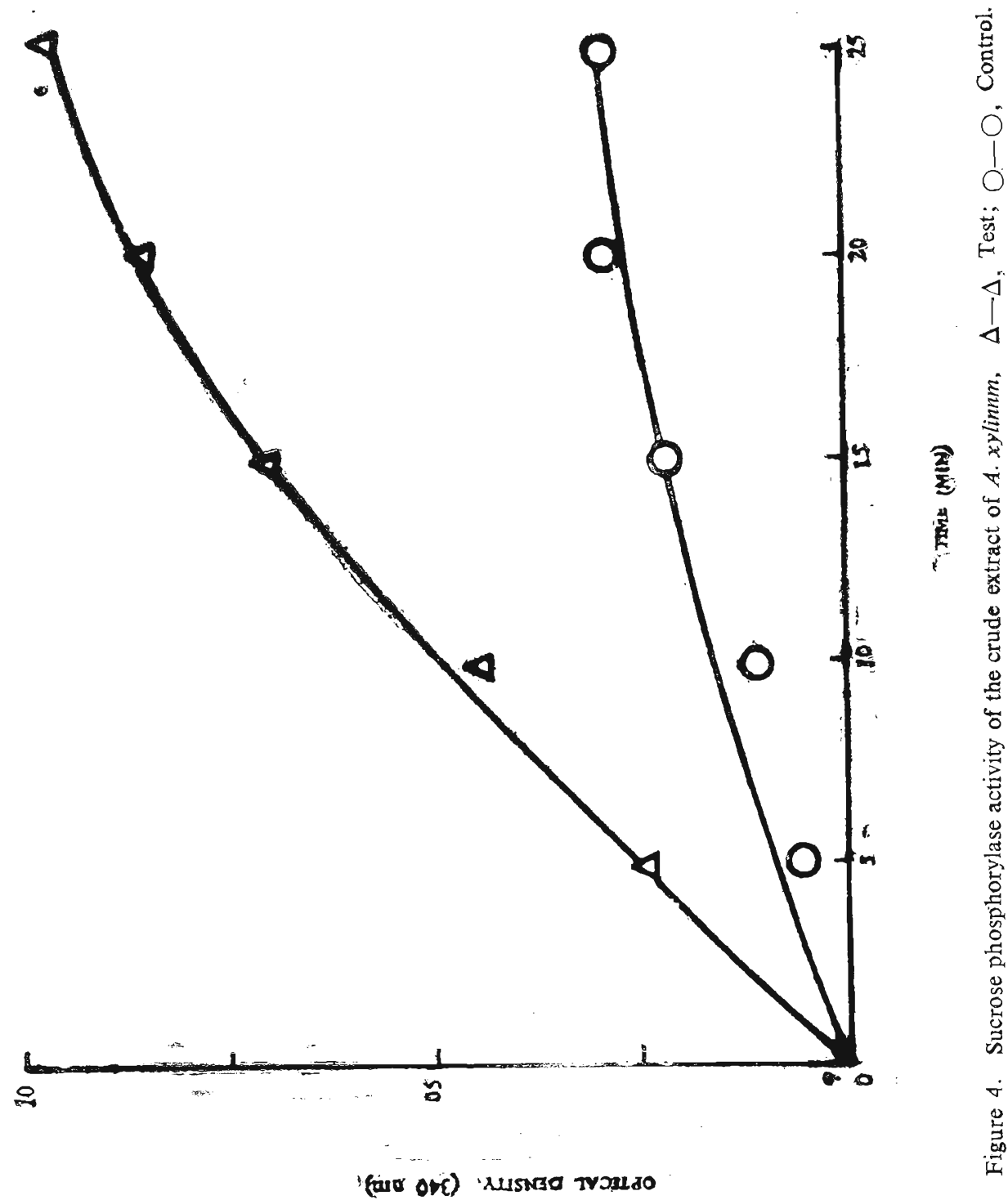


3.4. Inhibition of invertase activity

\subsubsection{Effect of EDTA on invertase activity}

Figure 5 shows the effect of EDTA on invertase activity of the Klebsiellu sp. and of the Leuconostoc sp. from catbage. $5 \times 10^{-2} \mathrm{M}$ EDTA inhibited the invertase activity of Klebsiella and Leuconostoc to the extent of $85 \%$ and $67 \%$ respectively.

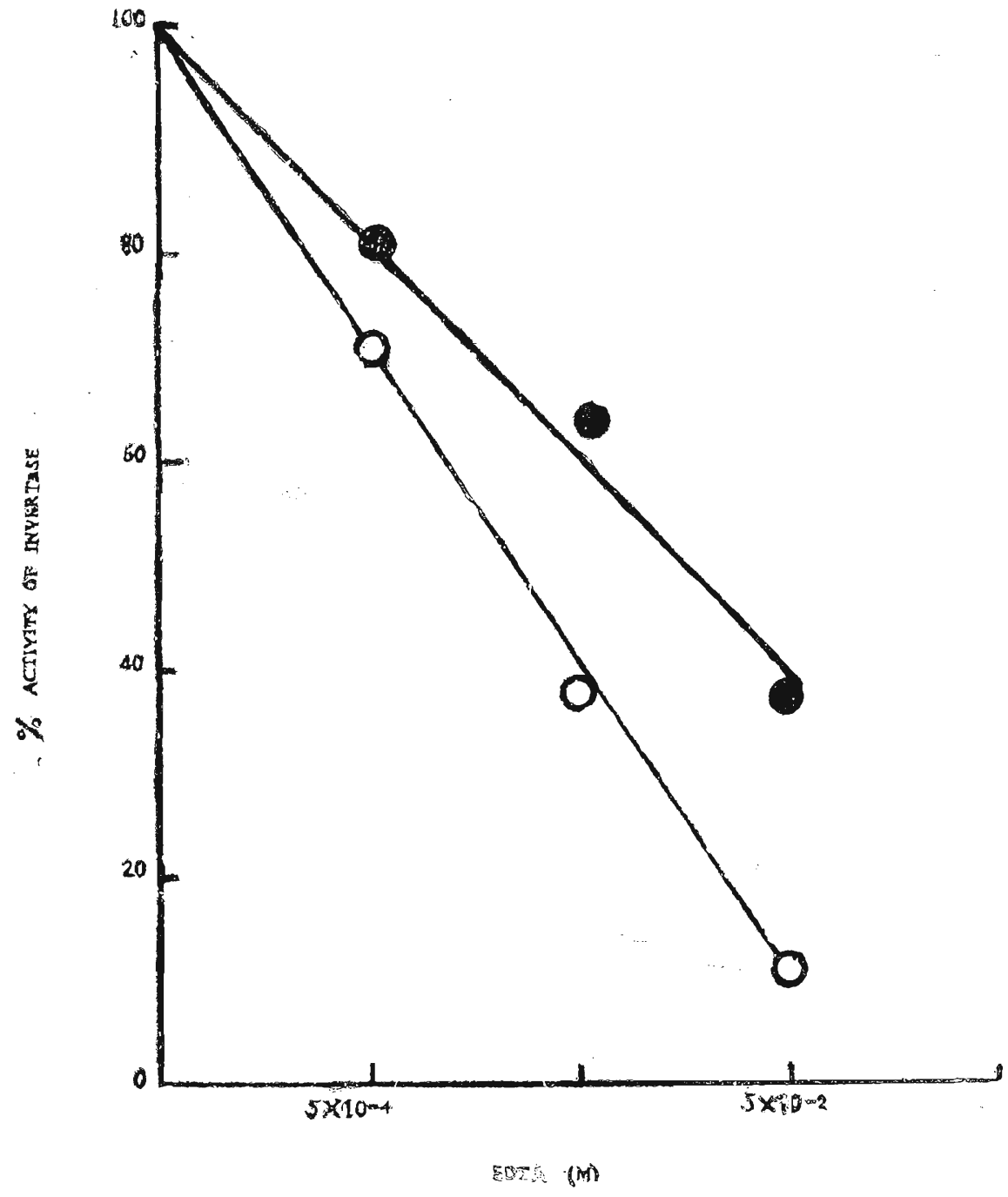

Figure 5. Effect of EDTA on invertase activity.

- - Leuconostoc sp.; O- O, Klebsiella sp. 
This inhibition by EDTA indicates that invertase of these bacteria might require a metal ion for its catalytic activity. Thus it is possible that bacterial invertase is a metallo enzyme. Confirmation of this observation will be of considerable interest. The other invertase that has been shown to require metal ion for its catalytic activity has been the coconlet invertase. ${ }^{1}$

\subsubsection{Effect of $\left(\mathrm{NH}_{4}\right)_{2} \mathrm{SO}_{4}$ on invertase activity}

The crude extract of Klebsiella sp. of specific activity 7.3 units/mg protein was stored in half saturated $\left(\mathrm{NH}_{4}\right)_{2} \mathrm{SO}_{4}{ }^{12}$ overnight at $4{ }^{\circ} \mathrm{C}$ and then centrifuged at $20,000 \mathrm{~g}$ for 20 mins.

Invertase activity was not observed either in the $20,000 \mathrm{~g}$ supernatant or in its pellet fraction indicating that half saturated ammonium sulphate jnhibits invertase activity under these storage conditions (Table 2).

TABLE 2. Effect of Ammonium Sulphate on Invertase Activity.

\begin{tabular}{ccc}
\hline $\begin{array}{c}\text { Ammonium } \\
\text { sulphate } \\
\text { (Concentration) }\end{array}$ & $\begin{array}{c}\text { Optical density } \\
(540 \mathrm{~nm})\end{array}$ & $\begin{array}{c}\text { invertase activity } \\
(\mu \text { moles } / \mathrm{h})\end{array}$ \\
\hline 0.0 & 615 & 7.3 \\
$50 \%$ & 0 & 0 \\
\hline
\end{tabular}

\subsection{Measurement of phosphorylase activity in the presence of inhibitors for invertase and phosphatase.}

As suwrose phosphorylase and invertase compete for the same substrate, attempts were made to detect the sucrose phosphorylase that may be present in very small amounts by inhibiting the invertase using EDTA and half saturated ammonium sulphate.

Experiments were also designed to inhibit the phosphatase that may hydrolyse the glucose-1-phosphate formed, which forms the substrate for phosphoglucomutase in the assay system of sucrose phosphorylase.

The phosphatase inhibitors used were $0.01 \mathrm{M} \mathrm{NaF}, 0.025 \mathrm{M}$ tartrate and $0.5 \%$ formaldehyde. ${ }^{2,11,13}$

The assay mixture for sucrose phosphorylase was as described in section 2.6.2, but it contained in addition EDTA $(0.05 \mathrm{M}), \mathrm{NaF}(0.01 \mathrm{M})$, tartrate $(0.025 \mathrm{M})$ and formaldehyde $(0.5 \%)$. 
No sucrose phosphorylase activity could be detected in the two species of Leuconostoc from cabbage and toddy and the Klebsiella sp.

\subsection{Effect of EDTA on bacterial growth.}

Since sucrose phosphorylase is an 'adaptive' enzyme, an experiment was performed to induce sucrose phosphorylase in the Klebsiella sp. by growing them in a sucrosephosphate medium containing EDTA, the inhibitor of invertase.

Figure 6 shows the effect of EDTA on the growth of Klebsiella. The growth rate of bacteria decreased by twofold when $5 \times 10^{-2}$ M EDTA was present in the culture medium. The extract failed to show any sucrose phosphorylase activity indicating that the sucrose, even in the presence of EDTA, did not induce the synthesis of sucrose phosphorylase in this Klebsiella species.

\section{Conclusion}

These studies show that the invertase activity is not directly related to their growth rates in the three species of bacteria namely the Klebsiella sp. and the two species of Leuconostoc. However Acetobacter xylinum showed a good growth in the sucrose-phosphate medium at $\mathrm{pH} 5.5$ but had very low invertase activity. This suggests the involvement of an enzyme other than invertase in the breakdown of sucrose in this bacterium. Studies have shown this additional enzyme to be sucrose phosphorylase.

Studies on sucrose phosphorylase from Pseudomonas sacchrophila ${ }^{12}$ have shown the enzyme to be found in the soluble fraction of the cell. The molecular weight as determined by Sephadex gel filtration was 80,000 to 100,000 while that determined by SDS-gel electrophoresis was $50,000.12$ This suggests that the enzyme is composed of two identical subunits. The optimum $\mathrm{pH}$ for the phosphorylysis of sucrose has been shown to be $7.0 .1^{14}$

The sucrose phosphorylase from Acetobacter xylinum is found in the soluble fraction of the cell as it is in Pseudomonas saccharophila. ${ }^{14}$ The optimum $\mathrm{pH}$ for the growth of A.xylinum is 5.5 .

Work on the purification and kinetic studies of sucrose phosphorylase is in progress. It appears that invertase is the most common enzyme for sucrose hydrolysis in bacteria and sucrose phosphorylase is present only in certain bacteria in which the invertase is absent or present in very low levels. 


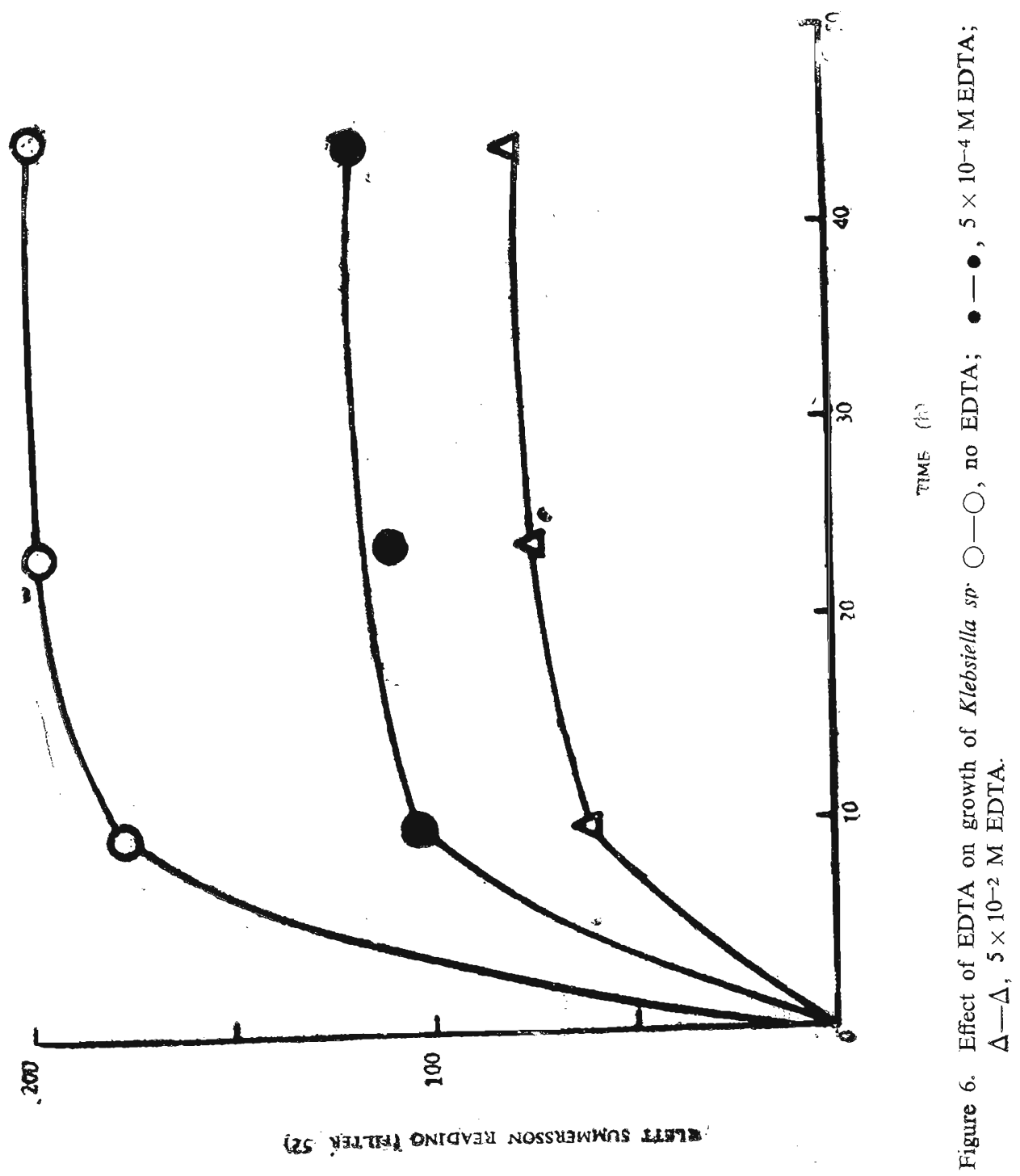




\section{Acknowledgements}

We thank the Natural Resources Energy and Science Authority of Sri Lanka for providing the grant for this study and the University of Colombo, Sri Lanka for providing the facilities. Our thanks to Dr. (Mrs.) M. C. P. Canagaratna for the helpful discussion and the Department of Microbiology and Industrial Development Board, for providing us with a sample of Klebsiella sp. and Acetobacter xylin um respectively. The technical assistance of Messrs O. D. H. R. Weerasena and R. D. Sothary is gratefully acknowledged.

\section{References}

1. Alles, N.H. (1977) M.Sc. Thesis. University of Colombo, Sri Lanka.

2. Balasubramaniam, K. \& Wijesundera, S. (1971). Ceylon J. Med. Sci. 30:52.

3. Butler, L.G., Squires, R.G. \& Kelly, S.J. (1977). Sugar y Azucar, 72:31.

4. Carr, J.G. (1968) Biological Principles of Fermentation. Eciucational Books Ltd., Heinemann, London.

5. Doudoroff, M. (1943) J. Biol. Chem. 151:351.

6. Doudoroff, M., Wiame, J.M. \& Wolochow, H. (1949) J. Bact. 57:423.

7. Hestrin, S., Feingold, D.S. \& Schramm, M. (1955) Meth. Enzym. 1:231. ed. S.P. Colowick and N.O. Kaplan, Academic Press Inc. New York.

8. KAGEN, B.O., LATKER, S.N. \& ZFASMAN, E.M. (1942) Biokhimiya 7:93.

9. Lampen, J.O. (1971) The enzymes. 5:291. ed P.D. Boyer 3rd ed. Academic Press Inc. New York.

10. Lowory, O.H., Rosebrough, N.J. Farr, A.L. \& Randall, R.J. (1951) J. Biol. Chem. 193:265.

11. Mathies, J.C. (1958) J. Biol. Chem. 233:1121.

12. Mieyal, J.J. (1973) Meth. Enzym. 28 (Part B):935. ed. V. Ginsburg. Academic Press Inc. New York.

13. Reiner, J.M., Tsuboi, K.K. \& Hudson, B. (1955) Arch. Biochem. Biophys. 56:165.

14. Silverstein, R., Voet, J., Reed, D. \& Abeles, R.H. (1967) J. Biol. Chem. 242:1338. 